\title{
NATIONAL FOOD SECURITY ACT 2013: MOVING FROM EXCLUSION TO INCLUSION
}

\author{
- Dipa Sinha and Biraj Patnaik
}

India has one of the lowest per capita daily supply of calories, protein and fat, according to the Organisation for Economic Co-operation and Development (OECD). ${ }^{1}$ One of the biggest contradictions of contemporary India is the unconscionably high rates of child malnutrition ${ }^{2}$ and the largest number of hungry people in the world, even as it emerged as one of the fastest growing economies. India has been a net exporter of foodgrains for more than a decade now ${ }^{3}$ and the government warehouses stock foodgrains at levels much higher than the required buffer norms. India has malnutrition levels almost double the levels of many countries in Africa. This problem needs a multi-sectoral approach including diet diversification, women's empowerment, education, health, safe drinking water, sanitation, and hygiene. ${ }^{4}$ The National Food Security Act (NFSA), 2013, which covers twothirds of the Indian population with subsidised food and universal entitlements for women and children, is a tentative first step towards solving this problem. There is a need for speedy implementation along with steps to avoid exclusion of poor households, and setting up an independent grievance redressal mechanism.

The National Food Security Act (NFSA) was legislated in 2013, as a result of a long struggle in the courts and outside to address the conundrum of hunger amidst plenty. In 2001, the Indian government had a surplus foodgrains stock of 60 million tonnes ${ }^{5}$ and yet a large number of hunger deaths were being periodically reported from across the country. It was also when the state of Rajasthan experienced its third successive year of drought and a leading human rights organisations in the country, People's Union for Civil Liberties (PUCL), approached the Supreme Court of India. Their plea was to make the right to food a justiciable right derived from Article 21 of the Indian Constitution that guarantees the right to life and liberty. While the petitioners had asked for relief for the state of Rajasthan, the Supreme Court extended the case across the country and made all the states/ Union Territories and relevant Union government agencies respondents in the case.

\section{FIGURE 1: PER CAPITA DAILY SUPPLY OF NUTRITION - 2011}

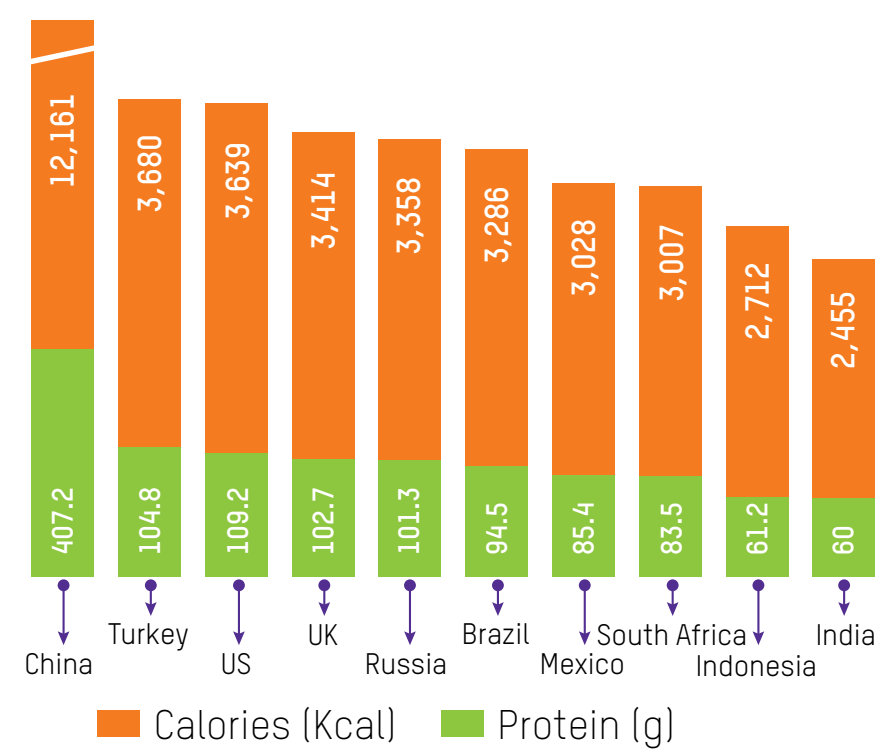

Source: Mint, 03 Dec 2015 Ihttp://www.livemint.com/Opinion/ GzUIDPQXzktVDBEiE2ZPfI/Per-capita-nutrition-supply-in-India-amongthe-lowest-in-the.html)
In what was to become the landmark 'right to food' case, the Court passed more than 200 orders, and considered the right to food as part of Article 21 of the Indian Constitution on the right to life. The Supreme Court went on to create justiciable entitlements for every age group of the population. The ambit of the interventions of the Court extended to universal entitlements for all children under the age of six, school meals for children in (government and government-aided) primary schools, the public distribution system, maternity entitlements, employment programmes, rights of the urban homeless and social security schemes like old age pensions. ${ }^{6}$

The Supreme Court case also galvanised a number of civil society organisations (CSOs) which included workers unions, women's organisations, and national networks working on rights of Dalits, Adivasis, persons with disability, transgender, sex workers, fisherfolk and other marginalised communities, to form the Right to Food Campaign (RTFC). The RTFC soon moved on to raise issues related to not just the Supreme Court orders but issues affecting these communities including land, forests, water, seeds, women's rights and specific entitlements of most vulnerable communities like shelter rights of the urban homeless.

The NFSA became part of the mainstream political agenda in 2009, when it found mention in the manifestos of almost all the major political parties in the country. In the discussion that ensued, the RTFC demanded that such a legislation should go beyond the Supreme Court orders and provide a lasting legislative framework for ensuring the right to food in India. The NFSA was passed in 2013, after four years of wide-ranging, often divisive, national debates that played out not just in TV studios and the editorial pages of newspapers, but also on the streets and the floor of Parliament.

The main debate on the NFSA centred around the coverage of the entitlement holders, with the government not wanting to go beyond the minimalist poverty line-sometimes called the 'starvation line' - set by the erstwhile Planning Commission while the RTFC demanded a universal entitlement. The final 
numbers were settled with the version of the draft negotiated by the National Advisory Council (NAC), an advisory body set up by the United Progressive Alliance I (UPA) consisting of civil society members, chaired by Sonia Gandhi who was the head of the UPA.

Many of the demands of the RTFC remained unfulfilled in the final version of the NFSA, particularly those pertaining to universalisation of all entitlements, an independent grievance redressal mechanism, farmer's rights, agriculture, land and water. It has been a prolonged struggle by the RTFC ${ }^{7}$ with critical support from the National Advisory Council ${ }^{8}$ to get the right to food "from the courts to the streets". ${ }^{9}$ The NFSA ${ }^{10}$ is a significant milestone in this ongoing struggle. Based on the past decade's experience, we make the following recommendations for proper implementation of NFSA to improve food security in the country.

\section{Recommendations}

- The government must identify entitlement holders using self-selection criteria

- The government must provide for adequate budgetary allocations for the Integrated Child Development Services (ICDS) and the Mid-Day Meal Scheme (MDMS)

- The government must ensure that the implementation of the Maternity Entitlements scheme is taken up with immediate effect

- The government must set up an independent grievance redressal mechanism within the NFSA

\section{Overview of Key Entitlements under NFSA}

With effect from 10 September 2013, the NFSA provides food and nutritional security in human life cycle approach, by ensuring access to adequate quantity of quality food at affordable prices to people to live a life with dignity. ${ }^{11}$ In real terms, the NFSA covers two-thirds of Indian population i.e. more than 820 million people across the country.

The NFSA provides for a free meal a day (either freshly cooked or ready to eat) for all children in the age group of 6 months to 6 years as well as pregnant and nursing women through anganwadi centres (AWCSs) run by ICDS. The Act also mentions that AWCs must be equipped with cooking, drinking water and sanitation facilities. ${ }^{12}$ Table 1 gives the norms set by the Act for the meals.

\section{TABLE 1: NATIONAL FOOD SECURITY ACT (NFSA) 2013 NORMS}

\begin{tabular}{|c|c|c|c|}
\hline Category & Type of Meal & $\begin{array}{l}\text { Calories } \\
\text { [Kcal] }\end{array}$ & $\begin{array}{l}\text { Protein } \\
\text { (g) }\end{array}$ \\
\hline $\begin{array}{l}\text { Children ( } 6 \text { months - } 3 \\
\text { years) }\end{array}$ & Take Home Ration & 500 & $12-15$ \\
\hline Children (3 - 6 years) & $\begin{array}{l}\text { Morning Snack and } \\
\text { Hot Cooked Meal }\end{array}$ & 500 & $12-15$ \\
\hline $\begin{array}{l}\text { Children ( } 6 \text { months } \\
\text { - } 6 \text { years) who are } \\
\text { malnourished }\end{array}$ & Take Home Ration & 800 & $20-25$ \\
\hline $\begin{array}{l}\text { Every Pregnant and } \\
\text { Lactating Mother during } \\
\text { pregnancy and for six } \\
\text { months after child birth }\end{array}$ & Take Home Ration & 600 & $18-20$ \\
\hline
\end{tabular}

Source : http://www.righttofoodcampaign.in/pre-school-nutrition/ official-documents
As mandated by the NFSA, schools ${ }^{13}$ are required to provide one free meal every day with specified nutritional standards, for all children of 6-14 years of age, or up till Class VIII through the MDMS. The guidelines for cooking or procuring these meals are issued by the Union government. ${ }^{14}$ The meals are to be prepared within the school premises in rural areas.

The Act also guarantees a maternity benefit of at least Rs. 6000 to all pregnant women except those working in government or public sector undertakings. In this regard, the Union government is required to implement a scheme to provide for the same.

Under the Act, 67 per cent of India's population (75 per cent of the rural population and 50 per cent of the urban population) are entitled to foodgrains at highly subsidised rates of Rs.3, Rs.2 and Re.1 per kg of wheat, rice and millets respectively ${ }^{15}$ through the Targeted Public Distribution System (TPDS). The entitlement holders of the TPDS have been divided into two categories. The 'priority' category entitles each person in the household to $5 \mathrm{~kg}$ of foodgrains per month totalling to $25 \mathrm{~kg}$ per month for a household of 5 persons.

Further, a second category of more vulnerable persons is defined by state governments as per the Union government guidelines and covered under the Antyodaya Anna Yojana. Under this category, the price rates offered to the beneficiaries are the same, but each beneficiary household is entitled to 35 $\mathrm{kg}$ of foodgrains, irrespective of the household size.

\section{Recommendations:}

\section{- The government must identify entitlement holders using self-selection criteria}

Many economists have lauded the 'self-selecting' design of the national right to work programme, the National Rural Employment Guarantee Act (NREGA). As Reetika Khera notes ${ }^{16}$, "With workfare programmes such as NREGA, it has been observed that the non-poor automatically select out of the programme. The requirement of performing physical labour and being paid the minimum wage for it keeps the non-poor with better opportunities out of the programme. The NREGA is a universal programme, yet it automatically selects-out the nonpoor. This is no mean achievement in policy design - correct identification of beneficiaries has been the undoing of many other welfare initiatives. "It might be worthwhile to adopt selfselection as a criteria to identify entitlement holders in the NFSA as well.

The standard poverty line method to identify beneficiaries of the TPDS before the ratification of the NFSA had been a subject of long-standing and complex debates. ${ }^{17}$ In order to overcome the challenges posed to the poverty line method and also improve identification of the poor/ beneficiaries, the government initiated the Socio-Economic Caste Census (SECC) in 2011 that was originally expected to conclude by 2011 . A preliminary launch of the SECC data was held in July 2015. It was expected that most states would use the data from the SECC for identification of the entitlement holders. ${ }^{18}$ The NFSA provides that the identification of beneficiaries for the purposes of the Act must be completed within 365 days of the commencement of the Act. ${ }^{19}$ 
However, there have been doubts raised on the accuracy and reliability of the SECC data ${ }^{20}$. To quote Surjit Bhalla ${ }^{21}$, the SECC data most likely overstate household income as it reports only the earnings of the highest earning member of the household. Another overstatement in the SECC relative to the National Sample Survey (NSS) is that while the former is an average for the period of July 2011 to 2013, the latter is for the agricultural year July 2011-June 2012. On average, the SECC 2011-13 income data is likely to be 14 per cent higher $(9$ per cent inflation and 5 per cent real growth) than the NSS 2011-12 data.

Additionally, there have been doubts raised about too many poor households being left out from SECC, even though theoretically, it can help eliminate leakages and errors of inclusion and exclusion. ${ }^{22}$ In this regard, states such as Bihar and Odisha are spelling out the exclusion criteria by stating that all those who are not excluded by the criteria set by the SECC survey should get the benefits of the NFSA. ${ }^{23}$ Madhya Pradesh, on the other hand, used a different database created by the state government (called the SAMAGRA portal) to identify cardholders. ${ }^{24}$ As of November 2015, NFSA has been implemented in 20 states and Union Territories. The deadline to roll it out expired on 30 September $2015 .^{25}$

- The government must provide for adequate budgetary allocations for the ICDS and the MDMS

Ironically, after the NFSA was legislated, there have been unprecedented cuts to the social sector budgets. Last year the budget for the ICDS ${ }^{26}$ was slashed by 50 per cent and the outlays for MDMS 27 have been cut by close to 30 per cent. This has further declined in the 2016-17 budget outlays. Drastic cuts have been made to education, health and social welfare programmes with a number of key programmes like the Backward Region Grant Fund (BRGF) having been phased out.

The ostensible reason that has been put forth to justify these cuts is that following the recommendations of the Fourteenth Finance Commission, the Centre has increased the states' share in the central divisible pool of taxes from 32 per cent to 42 per cent. ${ }^{28}$ The Union government claims that this will provide greater financial autonomy to the states, albeit, at the cost of a fiscal crunch for the Centre. ${ }^{29}$ However, enhanced allocation to these schemes is not reflected in the state budgets of 2015-16..$^{30}$

It is still not clear how they will be implemented at the same scale throughout the year. There is a fear that there will be an abrupt suspension of a number of programmes once the budget is exhausted. The Union government should immediately restore the budgets for the social sector progammes and inflationadjust them for the future years. There should be a re-look at these budgets, to upwardly revise the base year norms.

- The government must ensure that the implementation of the Maternity Entitlements scheme is taken up with immediate effect

One of the key features of the NFSA is the universal and unconditional maternity entitlement. The government has chosen to upgrade the maternity benefits from Rs. 4000 to Rs. 6000 (in two equal instalments) under the existing Indira Gandhi Matritva Sahyog Yojana (IGMSY) to realise the full mandate of the NFSA ${ }^{31}$. However, no additional budgetary provisions have been made beyond the 53 districts where the scheme is being piloted. Given the state of women's health in general, and more specifically of pregnant and nursing mothers, it is imperative that the maternity entitlement scheme be operationalised immediately.

The maternity entitlement programme should be implemented forthwith with retrospective effect, and arrears paid to all pregnant and nursing mothers from the date of the implementation, as specified by the NFSA.

- The government must set up an independent grievance redressal mechanism within the NFSA

In most states, the existing administrative staff have been notified as District Grievance Redressal Officers (DGROs) under the NFSA. Such a move seriously compromises the independence of the mechanism. This arrangement is riddled with conflict of interest as the same machinery that is meant to implement the act would also be responsible to identify and address failures in implementation of the act. Not a single independent State Commission has been similarly notified, and existing institutions have instead been designated to perform the functions of the State Commissions.

If the NFSA has to be successful, it needs a monitoring mechanism that is independent of the implementing machinery, much in the same way that the Right to Information Act provides for neutral ombudspersons. States should therefore appoint DGROs and State Commissions, bearing in mind the spirit of the NFSA, which envisaged an independent grievance redressal mechanism.

\section{Challenges}

Even if the NFSA were fully implemented, there remain several challenges. The Shanta Kumar Committee appointed by the National Democratic Alliance (NDA) government has, for instance, recommended a drastic restructuring of the food economy, including a reduction in the percentage of entitlement holders under NFSA from 67 per cent to 40 per cent. It also recommended the restructuring of the Food Corporation of India (FCI), and eventually replacing the Minimum Support Price (MSP) mechanism, which is the backbone of the PDS, with direct cash transfers. Clearly, the intent seems to be to whittle down the NFSA completely.

Similarly, the spiralling prices of pulses in the past few months have brought home the point that the RTFC and activists have made for long, i.e. to have a price stabilisation mechanism similar to cereals, by including pulses in the PDS. Other essential commodities such as cooking oil need to be included in the PDS as well.

In conclusion, legislating a socio-economic right while necessary is not sufficient for realisation of the right. The battle for ensuring that every single entitlement holder, all 820 million of them, benefit from the entitlement is a continuing battle. Till then, the NFSA will remain in contested terrain in the current environment of fiscal conservatism.

For the civil society, the roadmap ahead is to continue to use all democratic avenues available to them, including the courts; popular mobilisation; mass action and legislative advocacy to ensure that the dream of a hunger-free India is achieved. 
1 http://www.livemint.com/Opinion/GzUIDPQXzktVDBEiE2ZPfl/ Per-capita-nutrition-supply-in-India-among-the-lowest-inthe.html

2 See data from the Rapid Survey on Children (2013) available at http://wcd.nic.in

3 See for example: http://www.thehindubusinessline.com/ opinion/columns/c-p-chandrasekhar/the-politicaleconomy-of-food-exports/article4570293.ece and http:// r4d.dfid.gov.uk/PDF/Outputs/ChronicPoverty_RC/CPRCIIPA44.pdf

4 https://www.oxfamindia.org/sites/default/files/VII.\%20 Food \%20Security\%20in\%20India-Performance \%2C \%20 Challenges\%20and\%20Policies.pdf

5 Patnaik, B. (2012, June). Rio+20 India Case Study: India's Supreme Court remains the lynchpin in 11-year public battle to tackle hunger. Retrieved from OXFAM: https://www.oxfam.org/ sites/www.oxfam.org/files/oxfam-rioplus20-case-studyindia-jun2012.pdf

6 http://www.sccommissioners.org/FoodSchemes/ foodschemes.html

7 See website http://www.righttofoodcampaign.in/

8 Vivek, S., \& Sudha, N. (2007). Food Policy and Social Movements: Reflections on the Right to Food Campaign in India. In P. Pinstrup Andersen, \& F. Cheng, Food Policy for Developing Countries: The Role of Government in the Global Food System (p. 8). Ithaca, New York: Cornell University.

9 Dreze, J. (n.d.). Right to Food: From the Courts to the Streets. Retrieved May 22, 2015, from Right to Food India: http:// righttofoodindia.org/data/dreze-courts.pdf

10 The original text of the Act can be found here: http://indiacode. nic.in/acts-in-pdf/202013.pdf

11 http://dfpd.nic.in/nfsa-act.htm

12 Source: The Right to Food website. See http://www. righttofoodcampaign.in/pre-school-nutrition/officialdocuments

13 Schools run by local bodies and government as well as government aided schools from the private sector.

14 Ibid. See http://www.righttofoodcampaign.in/school-meals/ official-documents

15 State governments may choose to provide wheat flour instead of wheat and the price may be revised after 3 years.

16 http://www.indiaspend.com/cover-story/the-whys-andwhats-of-indias-rural-jobs-scheme-99284
17 Mitra, S. (2013, September 21). The Debate on Poverty Measures in India. Retrieved from Centre for Budget and Governance Accountability: http://www.cbgaindia.org/files/featured_ articles/The\%20Debate\%200n\%20Poverty\%20Measures.pdf

18 Parsai, G. (2013, July 21). Caste census data to be used to identify beneficiaries of Food Security Bill. Retrieved from The Hindu: http://www.thehindu.com/news/national/castecensus-data-to-be-used-to-identify-beneficiaries-of-foodsecurity-bill/article4935890.ece

19 See National Food Security Act, 2013, Chapter IV. Sec. 10 (b). Pp. 4-5.

20 http: / / www.thehindu.com/opinion/op-ed/castereservation-quantifying-the-caste-quotes/article8281303. ece

$21 \mathrm{http} / /$ indianexpress.com/article/opinion/columns/howbad-is-the-secc-data/

22 http://www.epw.in/system/files/pdf/2015_50/30/Socio_ Economic_Caste_Census.pdf

23 http://www.thehindubusinessline.com/economy/odishabihar-spell-out-exclusion-criteria-under-food-security-act/ article5526891.ece

24 http://nfsa.samagra.gov.in/

25 http://www.business-standard.com/article/economypolicy/govt-clears-additional-foodgrain-to-non-nfsastates-115110501546_1.html

26 The BE for ICDS has become less than half from last year's- Rs. 8754 crores from Rs. 18391 crores.

27 The BE for MDMS has been similarly almost halved from Rs. 13215 crores in 2014-15 to Rs. 7775 crores in 2015-16.

28 Government of India. (2014-15). The Fourteenth Finance Commission (FFC) - Implications for Fiscal Federalism in India? Retrieved from India Budget: http://indiabudget.nic.in/ es2014-15/echapvoll-10.pdf

29 Jaitley, A. (2015, February 28). Full text of Budget 2015-16 speech. Retrieved from The Hindu: http://www.thehindu. $\mathrm{com} /$ news/resources/full-text-of-budget-201516-speech/ article6945026.ece

$30 \mathrm{http} / /$ www.business-standard.com/article/economypolicy/govt-to-spend-rs-19-000-cr-more-on-social-sectorover-budget-estimates-115080300028_1.html

31 Falcao, V. L., \& Khanuja, J. (2015, March 30). India's unrealised maternity entitlement. Retrieved from The Hindu: http://www. thehindu.com/opinion/op-ed/indias-unrealised-maternityentitlement/article7040790.ece

Authors: Dipa Sinha teaches Economics at the School of Liberal Studies, Ambedkar University, Delhi. Biraj Patnaik is the Principal Adviser to the Commissioners of the Supreme Court in the Right to Food case.

Contributors: Oommen C Kurian, Pooja Parvati

Inputs: Nisha Agrawal, Vanita Suneja, Ranu Kayastha Bhogal, Rajita Kurup

Editing: Oommen C Kurian, Pooja Parvati

(c) Oxfam India April 2016.

This publication is copyright but the text may be used free of charge for the purposes of advocacy, campaigning, education, and research, provided that the source is acknowledged in full. The copyright holder requests that all such use be registered with them for impact assessment purposes. For copying in any other circumstances, permission must be secured. E-mail: policy[axfamindia.org.

Oxfam India, a fully independent Indian organization, is a member of an international confederation of 17 organizations. The Oxfams are rights-based organizations, which fight poverty and injustice by linking grassroots interventions to local, national, and global policy developments.

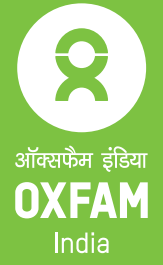

